Open Access

\title{
Multiple antibiotic resistances among Shiga toxin producing Escherichia coli 0157 in feces of dairy cattle farms in Eastern Cape of South Africa
}

Benson C. Iweriebor ${ }^{1,2^{*}}$, Chinwe J. Iwu ${ }^{1,2}$, Larry C. Obi ${ }^{3}$, Uchechukwu U. Nwodo ${ }^{1,2}$ and Anthony I. Okoh ${ }^{1,2}$

\begin{abstract}
Background: Shiga toxin-producing Escherichia coli (STEC) 0157:H7 is a well-recognized cause of bloody diarrhea and hemolytic-uremic syndrome (HUS). The ability of STEC strains to cause human disease is due to the production of Shiga toxins. The objectives of this study were to determinate the prevalence, serotypes, antibiotic susceptibility patterns and the genetic capability for Shiga toxin production in Escherichia coli (STEC) strains isolated from dairy cattle farms in two rural communities in the Eastern Cape Province of South Africa.

Methods: Fecal samples were collected between March and May 2014, from individual cattle $(n=400)$ in two commercial dairy farms having 800 and 120 cattle each.

Three hundred presumptive isolates obtained were subjected to polymerase chain reactions (PCR) for identification of O157 serogroup and Shiga toxin producing genes (stx1, stx2) on genomic DNA extracted by boiling method.

Susceptibility of the isolates to 17 antibiotics was carried out in vitro by the standardized agar disc-diffusion method.

Results: Based on direct PCR detection, 95 (31.7\%) isolates were identified as 0157 serogroup. The genetic repertoire for Shiga toxin production was present in $84(88.42 \%)$ isolates distributed as stx1 (37), stx2 (38) and stx1/2 (9) respectively while 11 of the isolates did not harbor Shiga toxin producing genes. Multiple antibiotic resistances were observed among the isolates and genetic profiling of resistance genes identified bla $a_{\mathrm{ampc}} 90 \%$, bla $a_{\mathrm{CMY}} 70 \%$,

bla $a_{\text {CTX-M }} 65 \%$, bla TEM $27 \%$ and tetA $70 \%$ and strA $80 \%$ genes among the antimicrobial resistance determinants examined.
\end{abstract}

Conclusion: We conclude that dairy cattle farms in the Eastern Cape Province are potential reservoirs of antibiotic resistance determinants in the province.

Keywords: E.coli, Shiga toxins, Antibiotic susceptibility, Cattle, STEC

\section{Background}

Escherichia coli is an important pathogen in cattle, medicine and public health [1], and Shiga toxin-producing strain (STEC) have emerged as important food-borne pathogens, especially serotype O157:H7. Human diseases

\footnotetext{
* Correspondence: biweriebor@ufh.ac.za

'SA-MRC Microbial Water Quality Monitoring Centre, University of Fort Hare, Alice 5700 , South Africa

${ }^{2}$ Applied and Environmental Microbiology Research Group, Department of Biochemistry and Microbiology, University of Fort Hare, Alice 5700, South Africa

Full list of author information is available at the end of the article
}

caused by this serotype that produces STEC ranges from mild diarrhoea to haemorrhagic colitis and haemolytic uraemic syndrome (HUS) and typically it affects children, the elderly, and immunocompromised patients [2]. Healthy domestic ruminants such as cattle, sheep, and goats can harbor STEC and E. coli O157:H7 in their faeces and are thus natural reservoirs of these pathogens [3-5]. The pathogenicity of STEC resides in a number of virulence factors, including Shiga toxins (Stx1 and Stx2), intimin, enterohaemolysin, and the STEC autoagglutinating adhesin (Saa) [6]. Shiga toxin-producing (STEC) and 
enteropathogenic Escherichia coli (EPEC) represent two of the six different categories of diarrheagenic $E$. coli that can cause disease in humans [1]. STEC, which is defined by the production of two Shiga toxins, Stx 1 and/or Stx2, is a zoonotic pathogen that is a major cause of diarrhea worldwide. Stx2 is more closely related to these diseases than stx1 [7]. There are three Stx1 subtypes (Stx1a, Stx1c, and Stx1d) and seven Stx2 subtypes (Stx2a, Stx2b, Stx2c, Stx2d, Stx2e, Stx2f, and Stx2g) according to the subtyping nomenclature proposal put forth at the 7th International Symposium on Shiga Toxin (Verocytotoxin)-Producing Escherichia coli Infection, held in Buenos Aires, in 2009.

The use of antimicrobial in animal feeds as growth promoters is common worldwide. Across the globe, a variety of antimicrobial agents are available for therapeutic use or as growth promotion in animals. Many studies have supported the claim that with the increased use of antimicrobial agents in animals and humans, an increased prevalence of resistant strains may be selected as a direct consequence of the antimicrobial use $[8,9]$. Humans, via the food chain, ingest a lot of bacteria originating from food-producing animals, which have been recognized as major reservoirs of $E$. coli habouring CTX-M $\beta$-lactamase an enzyme that confers resistance to $\beta$-lactam antibiotics [23]. Sasaki [10] have reported a high prevalence of CTX-M $\beta$-lactamase encoding gene among Enterobacteriaceae in stool specimens from healthy asymptomatic volunteers in a rural community in Thailand. Concerns exist about the potential spread of the $\beta$-lactam-CTX-M genes from food animal products to humans through the food chain. CTX-M $\beta$ lactamase genes have been reported in E. coli from various food-producing animals worldwide raising a potential threat to public health [11-16]. Giving the frequent occurrence of O157 STEC as foodborne pathogen in North America and some parts of the western world, there is a clear need to gather data on the prevalence and distribution of STEC producing E.coli and the antibiotic resistance profiles of isolates of this organism recovered from faecal samples from commercial dairy cattle farms in the Eastern Cape of South Africa where pastoral farming is a major source of income for many families. This study therefore aimed at characterizing E.coli $\mathrm{O} 157$ isolates from fecal samples of two dairy cattle farms in the Eastern Cape Province of South Africa. Ability of isolates to produce Shiga toxin and their antibiotic susceptibility patterns as well as presence of some resistance determinants were screened by molecular approaches.

\section{Methods}

\section{Ethical clearance}

Ethical clearance was obtained from the University of Fort Hare ethics committee prior to sample collection and permission was sought from farmers from whose farms samples were collected.

\section{Study population and sampling}

Details on the study population and sampling procedures are as follows. Briefly, samples were collected from commercial dairy cattle farms in Nkonkobe District of Eastern Cape Province, South Africa. A total of 400 samples from two commercial dairy farms were collected for the study. Rectal fecal grab samples of approximately $10 \mathrm{~g}$ were collected from individual cattle using sterile gloves into appropriate capped containers. After collection, samples were shipped on ice to the University of Fort Hare Microbiology laboratory for immediate processing.

\section{Preliminary sample processing}

Approximately $1 \mathrm{~g}$ of each fecal sample was mixed in $9 \mathrm{ml}$ of Trypticase soya broth (TSB) with $20 \mathrm{mg} / \mathrm{L}$ novobiocine and incubated for $6-8 \mathrm{~h}$ at $37{ }^{\circ} \mathrm{C}$. This was streaked out onto sorbitol MacConkey agar (SMAC) supplemented with $1 \mathrm{mg} / \mathrm{L}$ potassium tellurite and incubated for $18-24$ h at $37{ }^{\circ} \mathrm{C}$. A pale colony each (sorbitol nonfermenters) was picked as presumptive E. coli O157 per sample. The pure colonies were each inoculated into separate TSB and incubated for $24 \mathrm{~h}$ at $37^{\circ} \mathrm{C}$ from which glycerol stock was made and then stored at $-80{ }^{\circ} \mathrm{C}$ for further analyses.

\section{DNA extraction}

Bacterial DNA was prepared as previously described by Bai [17]; briefly, bacterial culture from glycerol stock was resuscitated by an overnight growth in trypticase soya broth (TSB) (Oxoid Ltd, London, UK) at $37^{\circ} \mathrm{C}$ with slight agitation. From this culture, $2 \mathrm{ml}$ was centrifuged for $5 \mathrm{~min}$ at 14,000 rpm and the pellet was washed with normal saline $(0.85 \% \mathrm{NaCl})$. After the addition of $150 \mu \mathrm{l}$ of rapid lysis buffer $(100 \mathrm{mM} \mathrm{NaCl}, 10 \mathrm{mM}$ Tris- $\mathrm{HCl}$ pH8.3, 1 mM EDTA pH9.0; 1 \% Triton X-100), the suspension was votexed, boiled for $15 \mathrm{~min}$, centrifuged at $10,000 \mathrm{rpm}$, supernatants collected in a DNase free Eppendorf tube and stored at $-20{ }^{\circ} \mathrm{C}$. These were then used as templates in all the polymerase chain reactions (PCRs) that were performed in this study.

\section{Molecular serotyping and virulence typing}

Molecular serotyping using the O-unit flippase gene $(w z x)$ was performed: primers used for detection of O157 strains are shown in Table 1. E. coli O157:H7 ATCC 35150 served as the positive control. Specific primers were used to detect the presence of virulence genes encoding the Shiga-toxins (stx 1 and $s t x 2$ ) as previously described by $[17,18]$. Amplification was performed using $25 \mu \mathrm{l}$ of PCR mix containing $5 \mu \mathrm{l}$ of bacterial DNA purified as described above, $12 \mu \mathrm{l}$ of $2 \mathrm{X}$ Dream 
Table 1 Primers used in PCR detection of Shiga toxin genes and determination of serotypes

\begin{tabular}{llll}
\hline Target gene & Primer sequences 5'-3' & $\begin{array}{l}\text { Size of } \\
\text { product (bp) }\end{array}$ & Reference \\
\hline stx1 & STx1-F TTC GCT CTG CAA & 555 & {$[18]$} \\
& TAG GTA & & \\
& STx1-R TTC CCC AGT TCA & & \\
& ATG TAA GAT & & \\
stx2 & STx2-F GTG CCT GTT ACT & 118 & {$[18]$} \\
& GGG TाT TTC TTC & & \\
& STx2-R AGG GGT CGA TAT & & \\
& CTC TGT CC & & \\
rfbE(O157) & rfbE-F TIT CAC ACT TAT & 88 & \\
& TGG ATG GTC TCA A & & \\
& rfbE-R CGA TGA GTT TAT & \\
& CTG CAA GGT GAT & \\
\hline
\end{tabular}

Taq Master Mix (Thermo Scientific), 10pmol of both forward and reverse primers and $6 \mu$ l of water of PCR grade. The conditions for PCR amplification performed in a thermal cycler (BioRad) were $94{ }^{\circ} \mathrm{C}$ for $3 \mathrm{~min}$, followed by 35 cycles of $93{ }^{\circ} \mathrm{C}$ for $60 \mathrm{~s}$, either $55{ }^{\circ} \mathrm{C}$ for $60 \mathrm{~s}$ and $72{ }^{\circ} \mathrm{C}$ for $60 \mathrm{~s}$. The final cycle was followed by an extension step at $72{ }^{\circ} \mathrm{C}$ for $7 \mathrm{~min}$. The amplified products were visualized by standard gel electrophoresis using $5 \mu \mathrm{l}$ of the PCR product on $2 \%$ agarose gels in $0.5 \mathrm{X}$ TBE buffer $(0.1 \mathrm{M}$ Tris, $0.1 \mathrm{M}$ boric acid and $0.002 \mathrm{M} \mathrm{NaEDTA})$. Gels were stained using ethidiumbromide $(1 \mathrm{mg} / \mathrm{ml})$ and photographed under UV light in a transilluminator (ALLIANCE 4.7).

\section{Antimicrobial drug susceptibility testing}

We determined antimicrobial drug susceptibility by the disk-diffusion method on Mueller-Hinton agar plates as recommended by the Clinical Laboratory Standard Institute [19]. We tested the following antimicrobial agents: ampicillin $10 \mu \mathrm{g}$, tetracycline $30 \mu \mathrm{g}$, oxy-tetracycline $30 \mu \mathrm{g}$, which were used in the farms and the following agents used in the management of E.coli infections; amoxicillin/clavulanic acid $10 \mu \mathrm{g}$, cephalothin $30 \mu \mathrm{g}$, cefotaxime $30 \mu \mathrm{g}$, ceftazidime $30 \mu \mathrm{g}$, imipenem $10 \mu \mathrm{g}$, norfloxacin $10 \mu \mathrm{g}$, ciprofloxacin $5 \mathrm{ug}$, enrofloxacin $5 \mu \mathrm{g}$, amikacin $30 \mathrm{ug}$, chloramphenicol $10 \mu \mathrm{g}$, kanamycin $30 \mu \mathrm{g}$, streptomycin $10 \mu \mathrm{g}$, gentamicin $10 \mu \mathrm{g}$ and sulfamethoxazole/trimethoprim (cotrimoxazole) $25 \mu \mathrm{g}$ (Mast Diagnostics). Results obtained were used to classify isolates as being resistant or susceptible to a particular antibiotic using standard reference values [19].

\section{PCR profiling of resistance genes}

Template DNA was prepared as previously stated above. The $\beta$-lactamase genes bla $a_{\mathrm{TEM}}, b l a_{\mathrm{SHV}}, b l a_{\mathrm{CMY}-2}$, blaСТХ-м, bla-СтХ-м1, bla-СТХ-м9 and bla-ampC and two of the genes responsible for resistance to streptomycin (str $\mathrm{A})$ and tetracycline (tet $\mathrm{A})$ respectively were tested using specific primers in Table 2 as described previously in literatures (Forward et al., 2001, Guillaume et al., 2000, Thong et al., 2010). PCR was performed in a 25- $\mu \mathrm{l}$ mixture of $12 \mu \mathrm{l}$ of $2 \mathrm{X}$ Dream Taq Master Mix (Thermo Scientific, Pittsburgh, PA, USA), 10 pmol of each forward and reverse primer and $6 \mu \mathrm{l}$ water of PCR grade. The PCR mixture was subjected to a 3-min denaturation step at $94{ }^{\circ} \mathrm{C}$, followed by 35 cycles of $45 \mathrm{~s}$ at $94{ }^{\circ} \mathrm{C}, 45 \mathrm{~s}$ at $55^{\circ} \mathrm{C} /$ $57{ }^{\circ} \mathrm{C} / 50{ }^{\circ} \mathrm{C}$ depending on the primer set, and $60 \mathrm{~s}$ at $72^{\circ}$ $\mathrm{C}$, and a final elongation step of $7 \mathrm{~min}$ at $72{ }^{\circ} \mathrm{C}$. PCR

Table 2 Primers used to profile $\beta$-lactamases, tet(A) and strA genes in Escherichia coli

\begin{tabular}{|c|c|c|c|}
\hline $\begin{array}{l}\text { Gene } \\
\text { detected }\end{array}$ & $\begin{array}{l}\text { Primer sequence } \\
\left(5^{\prime}-3^{\prime}\right)\end{array}$ & Size (bp) & Reference \\
\hline \multirow[t]{2}{*}{ blaTEM } & $\begin{array}{l}\text { CF- TCG GGG AAA TGT } \\
\text { GCG CG }\end{array}$ & & \\
\hline & $\begin{array}{l}\text { DR-TGC TTA ATC AGT } \\
\text { GAG GCA CC }\end{array}$ & 971 & [20] \\
\hline \multirow[t]{2}{*}{ blaSHV } & $\begin{array}{l}\text { OS-5 F- TTA TCT CCC TGT } \\
\text { TAG CCA CC }\end{array}$ & & \\
\hline & $\begin{array}{l}\text { OS-6R-GAT TTG CTG ATT } \\
\text { TCG CTC GG }\end{array}$ & 795 & [21] \\
\hline \multirow[t]{2}{*}{ blactX-M } & $\begin{array}{l}\text { MA-1 F-SCS ATG TGC AGY } \\
\text { ACC AGT AA }\end{array}$ & 158 & \\
\hline & $\begin{array}{l}\text { MA-2R- CCG CRA TAT GRT } \\
\text { TGG TGG TG }\end{array}$ & & [20] \\
\hline \multirow[t]{2}{*}{ blaCTX-M gp 9} & $\begin{array}{l}\text { M9UF-ATG GTG ACA AAG } \\
\text { AGA GTG CA }\end{array}$ & 863 & \\
\hline & $\begin{array}{l}\text { M9LR-CCC TTC GGC GAT } \\
\text { GAT TCT C }\end{array}$ & & [20] \\
\hline \multirow[t]{2}{*}{ blaCTX-M gp 1} & $\begin{array}{l}\text { M13UF-GGT TAA AAA ATC } \\
\text { ACT GCG TC }\end{array}$ & 863 & \\
\hline & $\begin{array}{l}\text { M13LR-TTG GTG ACG ATT } \\
\text { TTA GCC GC }\end{array}$ & & {$[20]$} \\
\hline \multirow[t]{2}{*}{ blaampC } & $\begin{array}{l}\text { AmpC1F-AAT GGG TाT TCT } \\
\text { ACG GTC TG }\end{array}$ & & \\
\hline & $\begin{array}{l}\text { AmpC2R-GGG CAG CAA ATG } \\
\text { TGG AGC AA }\end{array}$ & 191 & {$[22]$} \\
\hline \multirow[t]{2}{*}{ blaveB } & $\begin{array}{l}\text { casFF-CGA CTT CCA TTा CCC } \\
\text { GAT GC }\end{array}$ & & \\
\hline & $\begin{array}{l}\text { casBR -GGA CTC TGC AAC } \\
\text { AAA TAC GC }\end{array}$ & 1052 & [23] \\
\hline \multirow[t]{2}{*}{ blaCMY } & $\begin{array}{l}\text { CF1F-ATGATGAAAAAATCG } \\
\text { TTATGC }\end{array}$ & & \\
\hline & $\begin{array}{l}\text { CF2R-TTGTAGCTITTCAAGA } \\
\text { ATGCGC }\end{array}$ & 507 & {$[24]$} \\
\hline \multirow[t]{2}{*}{ tet(A) } & $\begin{array}{l}\text { TetA-F-GGCCTCAATTTCC } \\
\text { TGACG }\end{array}$ & & \\
\hline & $\begin{array}{l}\text { TetA-R-AAGCAGGATGTAG } \\
\text { CCTGTGC }\end{array}$ & 372 & {$[25]$} \\
\hline \multirow[t]{2}{*}{ strA } & $\begin{array}{l}\text { strA-F-CTTGGTGATAACG } \\
\text { GCAATTC }\end{array}$ & & \\
\hline & $\begin{array}{l}\text { strA-R-CCAATCGCAGAT } \\
\text { AGAAGGC }\end{array}$ & 548 & {$[26]$} \\
\hline
\end{tabular}


Table 3 Prevalence of Shiga toxin genes among the STEC O157 isolates

\begin{tabular}{llll}
\hline Serogroup & stx1 & stx2 & Prevalence of Shiga toxin genes \\
\hline O157 $(N=84)$ & + & - & $37(44 \%)$ \\
& - & + & $38(45.3 \%)$ \\
& + & + & $9(10.7 \%)$ \\
\hline
\end{tabular}

products were separated by $120-\mathrm{V}$ electrophoresis in a $2 \%$ agarose gel containing ethidium bromide for $45 \mathrm{~min}$, visualized in Alliance 4.7 transilluminator (ALLIANCE 4.7, Cambridge, United Kingdom) and photographed.

\section{Results}

\section{Serotyping}

PCR-based molecular serotyping using primers designed for detection of $\mathrm{O} 157$ group identified 95 positive isolates as O157 serotype (gel not shown) out of the 320 presumptive isolates.

\section{PCR-based detection of virulence genes}

The 95 molecularly confirmed E.coli O157 isolates were analyzed by PCR for their Shiga toxin producing capabilities. Table 3 shows PCR results of the different virulence genes for $84(88.45 \%)$ isolates detected among the 95 confirmed O157 isolates. The remaining 11 (11.55\%) though belonging to $\mathrm{O} 157$ serogroup, did not harbor Shiga toxin genes and were therefore regarded as nonSTEC strains.

Distribution of virulence genes among the 84 STEC strains showed that $37(44 \%)$ isolates possessed the stx 1 gene as shown in Fig. 1, 38 (45.3\%) possessed the $s t x 2$ gene Figure not shown while $9(10.7 \%)$ had both $s t x 1$ and stx 2 .

\section{Antibiotic sensitivity patterns}

Disk-diffusion susceptibility testing indicated high prevalence of multi-resistance to various antimicrobial agents among the 95 isolates: chloramphenicol $89.5 \%$, ampicillin $94.74 \%$, tetracyclin $96.84 \%$, oxytetracyclin $94.74 \%$, cefuroxime $82 \%$, ceftazidime $32 \%$, cephalothin $94.74 \%$, streptomycin $84.2 \%$, amikacin $6.3 \%$, kanamycin $5.3 \%$, amoxicillin/clavulanate $84.2 \%$, trimethoprim/sulfamethazole $84.2 \%$, norfloxacin $10.5 \%$, enrofloxacin $7.4 \%$, ciprofloxacin $12.6 \%$, and gentamycin $8.4 \%$ while all the isolates were susceptible to imipenem as shown in Table 4 below. All isolates showed reduced susceptibility to several antimicrobials agents in the panel.

\section{PCR profiling of resistance genes Prevalence of AMR genes}

Results of genetic profiling of the observed phenotypic resistances among the isolates showed predominance of bla $a_{\mathrm{ampC}} 90 \%$, bla $a_{\mathrm{CMY}} 70 \%$, bla $a_{\mathrm{CTX}-\mathrm{M}} 65 \%$, and $b l a_{\mathrm{TEM}}$ $27 \%$, among the isolates that were resistance to ampicillin, amoxicillin/clavulanate, cephalothin, cefuroxime, ceftazidime. PCR amplification of the bla $a_{\mathrm{SHV}}, b l a_{\mathrm{VEB}}$, bla $_{\text {CTX-Mgroup1 }}$ and bla $a_{\text {CTX-Mgroup } 9}$ did not yield any amplicon. The tet(A) and strA resistance genes were amplified from $70 \%$ and $80 \%$ respectively of the isolates that were phenotypically resistant to tetracycline, oxytetracycline and streptomycin.

Altogether, AMR genes were detected in all E. coli isolates. The most frequent resistance genes were tet(A), str(A), bla- ${ }_{\text {ampC, }}$ bla- ${ }_{\text {CMY-I }}$ (Table 5). With a very few exceptions, susceptibility test results were consistent with genotyping results. Gel photographs of some of the amplified resistance genes are shown in Figs. 2, 3 and 4. Overall, AMR genes were identified in $92 \%$ of the O157 isolates recovered from studied samples. Resistance genes detected from isolates as shown in Table 5.

\section{Discussions}

The prevalence of STEC O157 serogroup in fecal samples collected from commercial dairy cattle was investigated. Escherichia coli O157:H7 (O157) is the Shiga toxin-producing E. coli (STEC) serotype most frequently isolated and most often associated with hemolytic uremic syndrome (HUS) in the United States [2]. According to the U.S. Centers for Disease Control and Prevention, an estimated 265,000 STEC infections occur each year in the United States. STEC O157 causes about $36 \%$ of these infections and non-O157 STEC cause the rest [2]. STEC inhabits in the guts of ruminant animals, including cattle, goats, sheep, deer, and elk [2]. The major source for human illnesses is cattle and around 5-10\% of those who are diagnosed with STEC infection develop a potentially life-threatening complication known as hemolytic

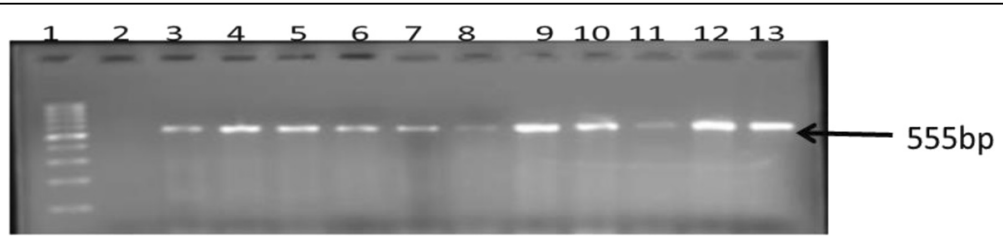

Fig. 1 Gel image of amplified PCR products from study isolates with primers designed for stx 1 virulent gene. Lane 1 is the MWM (100 bp), lane 2 is the negative control (PCR mix without DNA) with lane 3 as positive control (E. coli ATCC 35150) while lanes 4 to 13 are stx1 (555 bp) gene amplified from 0157 isolates 
Table 4 Antibiotic susceptibility pattern of E. coli O157:H7 $(n=95)$

\begin{tabular}{|c|c|c|c|c|c|}
\hline \multirow[t]{2}{*}{ Antibiotics class } & \multirow[t]{2}{*}{ Antimicrobial agents } & \multirow[t]{2}{*}{ Code } & \multirow[t]{2}{*}{ Potency $(\mu \mathrm{g})$} & $\mathrm{R}$ & \multirow[t]{2}{*}{$S$} \\
\hline & & & & $N(\%)$ & \\
\hline \multirow[t]{2}{*}{ Tetracycline } & Tetracycline & $\mathrm{T}$ & 30 & $92(96.8)$ & $3(3.3)$ \\
\hline & Oxytetracycline & OT & 30 & $90(94.7)$ & $5(5.3)$ \\
\hline \multirow[t]{2}{*}{ Penicillin } & Ampicillin & AMP & 10 & $90(94.7)$ & $5(5.3)$ \\
\hline & Amoxicillin/Claculanic acid & AUG & 10 & $80(84.2)$ & $15(15.8$ \\
\hline \multirow[t]{3}{*}{ Cephalospirines } & Cephalothin & KF & 30 & $90(94.7)$ & $5(5.3)$ \\
\hline & Ceftazidime & $C A Z$ & 30 & $30(32)$ & $65(78)$ \\
\hline & Cefuroxime & CXM & 30 & $78(82)$ & $17(18)$ \\
\hline Carbapenems & Imipenem & $\mid \mathrm{Ml}$ & 10 & $0(0)$ & $95(100)$ \\
\hline Phenicols & Chloramphenicol & CIP & 10 & $85(89.5)$ & $10(10.5$ \\
\hline \multirow[t]{4}{*}{ Aminoglycosides } & Amikacin & AK & 30 & $6(6.3)$ & $89(93.7)$ \\
\hline & Kanamycin & K & 10 & $5(5.3)$ & $90(94.7)$ \\
\hline & Streptomycin & $S$ & 10 & $80(80.2)$ & $15(15.8$ \\
\hline & Gentamycin & GM & 10 & $8(8.4)$ & $87(91.6)$ \\
\hline \multirow[t]{3}{*}{ Quinolones } & Ciprofloxacin & $\mathrm{CIP}$ & 5 & $12(12.6)$ & $83(87.4$ \\
\hline & Norfloxacin & NOR & 10 & $10(10.5)$ & $85(89.5$ \\
\hline & Enrofloxacin & ENR & 10 & $7(7.4)$ & $88(92.6)$ \\
\hline Foliate pathway inhibitor & Sulfamethazole/Trimethoprim & TS & 25 & $80(80.2)$ & $15(15.8$ \\
\hline
\end{tabular}

$R$ Resistant, $S$ Susceptible, $T$ Tetracycline, OT Oxytetracycline, AMP Ampicillin, AUG Amoxilcillin/clavulanic acid, KF Cephalothin, CXM Cefuroxime, CAZ Ceftazidime, C Chloramphenicol, IMI Imipenem, AK Amikacin, K Kanamycin, S Streptomycin GM Gentamycin, CIP Ciprofloxacin, NOR Norfloxacin, ERN Enrofloxacin, TS Sulphamethoxazole/Trimethoprim

uremic syndrome (HUS) with young children and the elderly more likely to develop severe illness and hemolytic uremic syndrome (HUS) than others.

In this study, a total of 400 fecal samples were collected from two commercial dairy farms in the Eastern Cape Province of South Africa. These samples were analyzed for the presence of O157 E.coli strain. A total of 95 isolates confirmed by PCR targeting the O-unit flippase gene $(w z x)$ were delineated to be $\mathrm{O} 157$ isolates. Results of the determination for the presence of Shiga toxin encoding gene (stx 1 and st $x 2)$ among the 95 isolates showed that $35(36.84 \%)$ harbored the stx1 gene, $26(27.4 \%)$ were positive for $s t x 2$ while $9(9.5 \%)$ harbored both $s t x 1$ and $s t x 2$ genes. Twenty five (26.3\%) of the isolates were commensals as no Shiga toxin genes were detected in them.

According to Gyles [3], ruminants especially cattle and sheep are the major reservoir of STEC and individual animal could carry more than one serogroups of STEC. During processing, meat derived from infected animals may become contaminated by STEC contained fecal materials if they are mistakenly mixed with it. Barlow and Mellor [27] had reported the presence of STEC in fecal samples of cattle from Australia where a prevalence of $10 \%$ was observed with E.coli O157 accounting for $1.7 \%$ of all the isolates. It is possible for fresh farm produce to be contaminated with STEC where irrigation water or soil treated with farm effluent or manure is used in growing them. A prevalence as high as $33.5 \%$ of STEC in bulk milk has been reported internationally [28]. It is also possible for STEC to survive for a long time in soil applied with manure from cattle and sheep. The possibility of water sources being contaminated by STEC is also very high as fecal materials of animal origin could be washed through storm drains into fresh waterbodies thus posing health challenges to the people who depend on such waterbodies for several uses. WHO [29] had reported waterborne transmission of STEC in both

Table 5 PCR targeted genes and their percentage occurrence among the isolates

\begin{tabular}{ll}
\hline Resistance gene profiled & Percentage of amplified genes \\
\hline bla- ${ }_{\text {ampc }}$ & $90 \%$ \\
bla- $_{\mathrm{CMY}}$ & $70 \%$ \\
bla $_{\mathrm{CTXM}}$ & $65 \%$ \\
Tet(A) & $70 \%$ \\
strA & $80 \%$ \\
bla & $27 \%$ \\
bla $_{\mathrm{SHV}}$ & $0 \%$ \\
bla $_{\mathrm{VEB}}$ & $0 \%$ \\
bla $_{\mathrm{CTXMgroup} 1}$ & $0 \%$ \\
bla $_{\mathrm{CTXM}-\mathrm{group} 9}$ & $0 \%$ \\
\hline
\end{tabular}




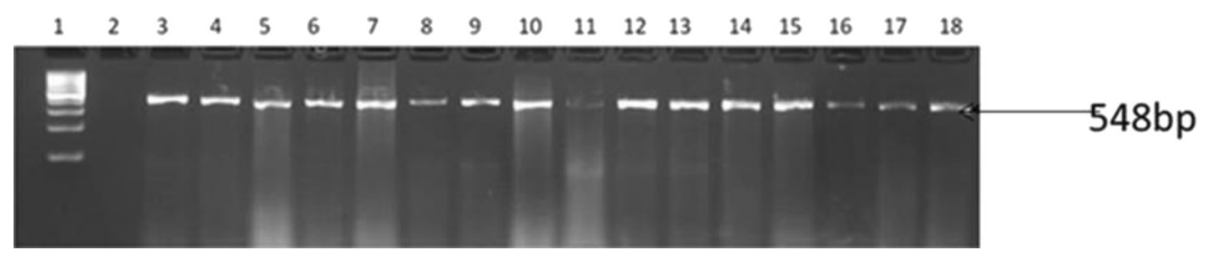

Fig. 2 Agarose gel images of amplicons obtained from PCR with primers designed for strA resistance gene of E. coli isolates recovered from this study. Lane 1 is molecular size markers (100 bp), lane 2 is negative control (PCR mix without DNA) while lanes 3 to 18 are strA (548 bp) gene from $\mathrm{O} 157$ strains isolated in this study

drinking and recreational water indicating the animal fecal matters are capable of transmitting STEC producing E.coli.

There are increasing concerns about the use of antimicrobial products in food-producing animals and focus has been on human food safety because foods of animal origin are sometimes identified as the vehicles of food borne disease as well as resistant food borne pathogens carrying resistant genetic materials. We profiled the antimicrobial susceptibility of E.coli O157 isolates recovered from commercial dairy cattle that are constantly receiving (tylosin, advocin, ampicillin, tetracycline) antimicrobial agents. We observed a very high level of multiple antimicrobial resistances among the isolates and the most common resistance was to tetracycline. This is not surprising since tetracycline is often used as a first-line antimicrobial in disease prevention and growth promotion in food animals and its widespread use has likely contributed to high rates of resistance [30]. The frequency of tetracycline resistance among the E. coli isolates from the farms that we investigated was $96.8 \%$, which is within the range of values described in previous reports (68 to $93 \%$ ) [31, 32]. Genetic profiling of the resistance determinants showed that the resistances were encoded by $b l a_{\mathrm{ampO}} b l a_{\mathrm{CMY}}, b l a_{\mathrm{CTXM}}, b l a_{\mathrm{TEM}}$ genes for the ESLBs (extended spectrum $\beta$-lactamases), while tetA and strA genes were responsible for tetracycline and streptomycin respectively. High prevalence of CTX-M $\beta$ lactamase-encoding genes in Enterobacteriaceae has been reported in stool specimens from healthy asymptomatic volunteers in a rural community in Thailand [11]. The fact that bacteria which infect animals could also establish infections in humans poses concerns about the potential spread of the bla- СтХ-M genes from food animal products to humans through the food chain. CTX-M $\beta$-lactamase has been increasingly reported in $E$. coli from various food-producing animals worldwide raising a potential threat to public health with the earliest account of CTX-M $\beta$-lactamase of food animal origin from Spain, where a CTX-M-14-producing E. coli was isolated from healthy chickens [33]. Since then, E.coli harboring CTX-M $\beta$-lactamase encoding gene has been reported from healthy cattle from Japan [34] and Hong Kong [35], and from sick or healthy cattle from France $[36,37]$ and in the United States [38, 39]. Similarly, E.coli strains isolated from pigs that have the genetic repertoire to produce CTX-M- $\beta$-lactamase have also been reported from Hong Kong [40], China [41], Spain [42], and France [36]. In this study, genetic resistance determinants were however not amplified from some of the isolates and this could be attributed to the fact that the genetic elements targeted in our PCR profiling were not responsible for the observed phenotypic resistances as there are numerous arrays of genes that encodes for resistances to the drugs. Besides, there are many resistance mechanisms like the efflux pump, intrinsic resistance, innate resistant or acquire resistance to one or few classes of antimicrobial agents. Our findings also showed that most of the isolates were susceptible to imipenem, amikacin, kanamycin, the quinolones (norfloxacin, ciprofloxacin and enrofloxxacin) and gentamicin. This finding is curious as regards the susceptibility to the quinolones because the farms that were sampled uses advocin (danofloxacin) which is a synthetic fluoroquinolone in the treatment of respiratory disease in chickens, cattle and pigs and ought to have selected for other quinolone

\section{$\begin{array}{lllllllllllllllllll}1 & 2 & 3 & 4 & 5 & 6 & 7 & 8 & 9 & 10 & 11 & 12 & 13 & 14 & 15 & 16 & 17 & 18\end{array}$}

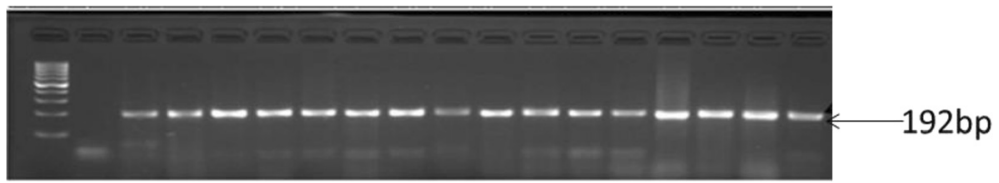

Fig. 3 Agarose gel image of amplicons obtained from PCR with primers designed for bla-ampc resistance gene of E. coli isolates recovered from this study. Lane 1 is molecular size markers (100 bp), lane 2 is negative control (PCR mix without DNA) while lanes 3 to 18 are bla-ampC (198 bp) gene from O157 strains isolated in this study 


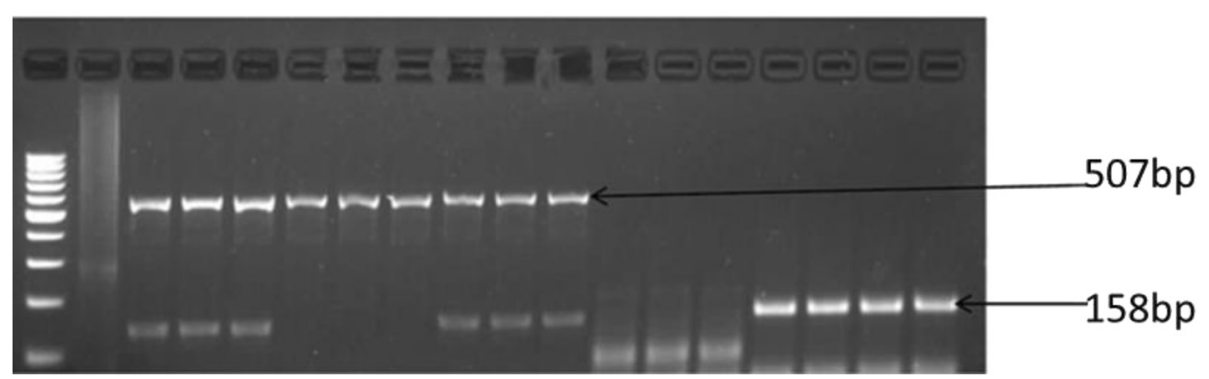

Fig. 4 Gel image of amplicons obtained from multiplex PCR with primers designed for bla- ${ }_{\mathrm{CMY}}$ and bla- ${ }_{\mathrm{CXT}-\mathrm{m}}$ resistance genes of $\mathrm{E}$ coli isolates recovered from this study. Lane 1 is molecular size markers (100 bp), lane 2 is negative control (PCR mix without DNA) while lanes 3 to 18 are bla-cMY (507bp) and bla-сXт-M (158 bp) genes from 0157 strains isolated in this study

resistances as they have similar structure and mode of action.

To understand the bases of high tetracycline resistance among our isolates, we screened for tet determinants. The predominance of the tet $(\mathrm{A})$ efflux gene observed in our study is similar to that previously documented in coliforms $(73 \%)$ of human and animal origins by Marshall [43]. In this study, we observed also a very high resistance to streptomycin among the isolates which is in partial agreement with the reported $53 \%$ resistance of E.coli O157 isolates from feedlots by Rao [44]. Also, Sawant [45] reported a prevalence of $93 \%$ of tetracycline resistance in E.coli of dairy cattle with tet(B) accounting for the resistance determinant in $93 \%$ of their isolates and this is similar to our finding though mediated by different variants of the gene.

The fact that bacteria from animals spread to the food products during slaughter and processing has been extensively documented [46-49]. The detection of E.coli resistant to antibiotic growth promoters (AGPs) in food products derived from animals where AGPs have been used therefore comes as no surprise. Resistant bacteria and active antibiotics, or active metabolites of antibiotics can also spread on farmland with manure. In this study, we isolated toxigenic O157 E.coli strains carrying stx1 and stx 2 genes that were also multi-resistant to many antibiotics some of which are medically important in human medicine. The possibility of these antibiotic resistant strains being shed into the environment and the eventual transmission of the resistance determinants to nonpathogenic environmental bacteria is high. Such transfer of resistance determinants could fuel the spread of antibiotic resistant bacteria (ARB) that could have grave implications on the health of humans and animals thus increasing the burden of disease in the community. There is therefore need for urgent policy formulations on the prudent use of antimicrobials in both human and veterinary medicine as failure in this regards could spell doom in the nearest future.

\section{Conclusions}

In conclusion, this study demonstrated that antimicrobial resistant (AMR) determinants were present in dairy cattle exposed to veterinary antimicrobials for both therapeutic and as growth promoting agents. The overall resistance rate was high and the isolates have the genetic repertoires to survive antimicrobial pressure. Though genetic capacity for Shiga toxins production have been reported among E.coli nonO157 serogroups, we did not profile for any other serogroups apart from $\mathrm{O} 157$ in the fecal samples analyzed. The observed phenotypic multiple resistances among the isolates were also genetically confirmed. There were high $\beta$-lactam resistances among the isolates and this poses health implications as these are the drugs of choice for the management of numerous Gram negative infections. The results of this study suggest that agricultural activities, specifically antimicrobial use may have a significant impact on AMR evolution in general. More studies with larger sample sizes and more precise AMR genes typing by DNA sequencing and molecular typing of bacterial strains are needed to further throw more light in this regard.

\section{Abbreviations}

STEC: Shiga toxin-producing E. coli; HUS: hemolytic uremic syndrome; stx1: Shiga toxins 1; stx2: Shiga toxins 2; TSB: trypticase soya broth; SMAC: sorbitol MacConkey agar; PCR: polymerase chain reaction; AMR: antimicrobial resistant; AGPs: antibiotic growth promoters; ARB: antibiotic resistant bacteria.

\section{Competing interest}

The authors declare that they have no competing interest.

\section{Authors' contributions}

$\mathrm{BCl}$ and $\mathrm{CJ}$ collected the fecal samples and performed the experiments, LCO and $\mathrm{AIO}$ designed and supervised the whole study as well as edited the manuscript; $\mathrm{BCl}, \mathrm{CJ}, \mathrm{UUN}$ and $\mathrm{LCO}$ analyzed the sample data and wrote the manuscript. All authors read and approved the final manuscript.

\section{Acknowledgments}

The authors wish to thank the University of Fort Hare and the South African Medical Research Council for financial support. 


\section{Author details}

${ }^{1}$ SA-MRC Microbial Water Quality Monitoring Centre, University of Fort Hare, Alice 5700, South Africa. ${ }^{2}$ Applied and Environmental Microbiology Research Group, Department of Biochemistry and Microbiology, University of Fort Hare, Alice 5700, South Africa. ${ }^{3}$ Academic and Research Division, University of Fort Hare, Alice, Eastern Cape, South Africa.

\section{Received: 30 June 2015 Accepted: 7 October 2015} Published online: 16 October 2015

\section{References}

1. Kaper JB, Nataro JP, Mobley HLT. Pathogenic Escherichia coli. Nat Rev Microbiol. 2004;2:123-40.

2. CDC MMWR. Outbreaks of Escherichia coli O157:H7 infections among children associated with farm visits_-Pennsylvania and Washington, 2000. MMWR. 2001;50(15):293-7.

3. Blanco M, Padola NL, Krüger A, Sanz ME, Blanco JE, González EA, et al. Virulence genes and intimin types of Shiga-toxin-producing Escherichia coli isolated from cattle and beef products in Argentina. Int Microbiol. 2004;7:269-76.

4. Orden JA, Cortes C, Horcajo P, De la Fuente R, Blanco JE, Mora A, et al. A longitudinal study of verotoxin-producing Escherichia coli in two dairy goat herds. Vet Microbiol. 2008;132:428-34.

5. Sanchez S, Martinez R, Rey J, Garcia A, Blanco J, Blanco M, et al. Phenogenotypic characterization of Escherichia coli 0157:H7 isolates from domestic and wild ruminants. Vet Microbiol. 2009;142:445-9.

6. Gyles CL. Shiga toxin-producing Escherichia coli: an overview. J Anim Sci. 2007;85:E45-62.

7. Siegler RL, Obrig TG, Pysher TJ, Tesh VL, Denkers ND, Taylor FB. Response to Shiga toxin 1 and 2 in a baboon model of hemolytic uremic syndrome. Pediatr Nephrol. 2003;18:92-6.

8. Donabedian SM, Thal LA, Hershberger E, Perri MB, Chow JW, Bartlett P, et al. Molecular characterization of gentamicin-resistant enterococci in the United States: evidence of spread from animals to humans through food. J Clin Microbiol. 2003;41:1109-13.

9. Hershberger E, Donabedian S, Konstantinou K, Zervos MJ. Quinupristindalfopristin resistance in gram-positive bacteria: mechanism of resistance and epidemiology. Clin Inf Dis. 2004;38:92-8.

10. Ho PL, Chow KH, Lai EL, Lo WU, Yeung MK, Chan J, et al. Extensive dissemination of CTX-M-producing Escherichia coli with multidrug resistance to "critically important" antibiotics among food animals in Hong Kong, 2008-10. J Antimicrob Chemother. 2011;66:765-8.

11. Sasaki T, Hirai I, Niki M, Nakamura T, Komalamisra C, Maipanich W, et al. High prevalence of CTX-M beta-lactamase-producing Enterobacteriaceae in stool specimens obtained from healthy individuals in Thailand. J Antimicrob Chemother. 2010;65:666-8.

12. Brinas L, Moreno MA, Zarazaga M, Porrero C, Saenz Y, Garcia M, et al. Detection of CMY-2, CTX-M-14, and SHV-12 b-lactamases in Escherichia coli fecal-sample isolates from healthy chickens. Antimicrob Agents Chemother. 2003;47:2056-8.

13. Duan RS, Sit THC, Wong SSY, Wong RCW, Chow KH, Mak GC, et al. Escherichia coli producing CTX-M b-lactamases in food animals in Hong Kong. Microb Drug Resist. 2006;12:145-8.

14. Li XZ, Mehrotra M, Ghimire S, Adewoye L. b-Lactam resistance and b-lactamases in bacteria of animal origin. Vet Microbiol. 2007:121:197-214.

15. Madec JY, Lazizzera C, Châtre P, Meunier D, Martin S, Lepage G, et al. Prevalence of fecal carriage of acquired expanded-spectrum cephalosporin resistance in Enterobacteriaceae strains from cattle in France. J Clin Microbiol. 2008;46:1566-7.

16. Wittum TE, Mollenkopf DF, Daniels JB, Parkinson AE, Mathews JL, Fry PR, et al. CTX-M-type expendedspectrum b-lactamases present in Escherichia coli from the feces of cattle in Ohio, United States. Foodborne Pathog Dis. 2010;7:1575-9.

17. Bai J, McAteer SP, Paxton E, Mahajan A, Gally DL, Tree JJ. Screening of an E. coliO157:H7 bacterial artificial chromosome library by comparative genomic hybridization to identify genomic regions contributing to growth in bovine gastrointestinal mucus and epithelial cell colonization. Front Microbiol. 2011;2:168. doi:10.3389/fmicb.2011.00168.

18. Franck SM, Bosworth BT, Moon HW. Multiplex PCR for enterotoxigenic, attaching and effacing, and Shiga toxin-producing Escherichia coli strains from calves. J Clin Microbiol. 1998;36:1795-7.
19. Clinical and Laboratory Standards Institute. Performance standards for antimicrobial susceptibility testing: twenty-fourth informational supplement M100-S21. Wayne (PA): The Institute; 2014. p. 2014.

20. Saladin M, Cao VT, Lambert T, Donay JL, Herrmann JL, Ould-Hocine Z, et al. Diversity of CTX-M beta-lactamases and their promoter regions from Enterobacteriaceae isolated in three Parisian hospitals. FEMS Microbiol Lett. 2002;209:161-8.

21. Arlet G, Rouveau M, Philippon A. Substitution of alanine for aspartate at position 179 in the SHV-6 extended-spectrum beta-lactamase. FEMS Microbiol Lett. 1997;152:163-7.

22. Forward KR, Willey BM, Low DE, Mcgeer A, Kapala MA, Kapala MM, et al. Molecular mechanisms of cefoxitin resistance in Escherichia coli from the Toronto area hospitals. Diagn Microbiol Infect Dis. 2001;41:57-63.

23. Poirel L, Naas T, Guibert M, Chaibi EB, Labia R, Nordmann P. Molecular and biochemical characterization of VEB-1, a novel class A extended-spectrum beta-lactamase encoded by an Escherichia coli integron gene. Antimicrob Agents Chemother. 1999;43:573-81.

24. Eckert C, Gautier V, Saladin-Allard M, Hidri N, Verdet C, Ould-Hocine Z, et al. Dissemination of CTX-M-type beta-lactamases among clinical isolates of Enterobacteriaceae in Paris, France. Antimicrob Agents Chemother. 2004:48:1249-55. doi:10.1128/AAC.48.4.1249-1255.2004.

25. Guillaume G, Verbrugge D, Chasseur-libotte M, Moens W, Collard J. PCR typing of tetracycline resistance determinants ( Tet A - E ) in Salmonella enterica serotype Hadar and in the microbial community of activated sludges from hospital and urban wastewater treatment facilities in Belgium. FEMS Microbiol Ecol. 2000;32:77-85

26. Thong KL. Characterization of drug resistant Salmonella enterica Serotype Typhimurium by antibiograms, plasmids, integrons, resistance genes and PFGE. J Microbiol Biotechnol. 2010;20(6):1042-52.

27. Barlow RS, Mellor GE. Prevalence of enterohemorrhagic Escherichia coli serotypes in Australian beef cattle. Foodborne Pathog Dis. 2010;7(10):1239-45

28. FSANZ. Microbiological risk assessment of raw cow milk. Australia New Zealand, Canberra: Food Standards; 2009. http://www.foodstandards.gov.au/ code/proposals/documents/P1007\%20PPPS\%20for\%20raw\%20milk\% 201AR\%20SD1\%20Cow\%20milk\%20Risk\%20Assessment.pdf. Accessed 31 May 2014.

29. WHO. Fact sheet No 125 - Enterohaemorrhagic Escherichia coli (EHEC). Geneva: World Health Organisation; 2011. http://www.who.int/mediacentre/ factsheets/fs125/en/. Accessed 18 August 2014.

30. Pihkala N, Bauer N, Eblen D, Evans D, Johnson R, Webb J, et al. Risk profile for pathogenic non-0157 Shiga toxin producing Escherichia coli (non-0157 STEC). Office of Policy and Program Development, USDA-FSIS: Office of Public Health Science; 2012. Available at: http://www.fsis.usda.gov/.PDF/ Non_O157_STEC_Risk_Profile_May2012.pdf, accessed March 1, 2013.

31. Cernicchiaro N, Cull CA, Paddock ZD, Shi X, Bai J, Nagaraja TG, et al. Prevalence of Shiga toxin-producing escherichia coli and associated virulence genes in feces of commercial feedlot cattle. Foodborne Pathog Dis. 2013;10(10):835-41.

32. Scheutz F, Strockbine NA. Escherichia. In: Garrity GM, Brenner DJ, Krieg NR, Staley JT, editors. Bergey's manual of systematic bacteriology. New York, NY: Springer; 2005. p. 607-24.

33. Renter DG, Morris Jr JG, Sargeant JM, Hungerford LL, Berezowski J, Ngo T, et al. Prevalence, risk factors, O serogroups, and virulence profiles of Shiga toxin producing bacteria from cattle production environments. J Food Prot. 2005;68:1556-65

34. Briñas $L$, Moreno MA, Teshager T, Sáenz $Y$, Porrero M, Domínguez $L$, et al. Monitoring and characterization of extended-spectrum $\beta$-lactamases in Escherichia coli strains from healthy and sick animals in Spain in 2003. Antimicrob Agents Chemother. 2005;49:1262-4.

35. Shiraki Y, Shibata N, Doi Y, Arakawa Y. Escherichia coli producing CTX-M-2 b-lactamase in cattle Japan. Emerg Infect Dis. 2004;10:69-75.

36. Duan RS, Sit TH, Wong SS, Wong RC, Chow KH, Mak GC, et al. Escherichia coli producing CTX-M $\beta$-lactamases in food animals in Hong Kong. Microb Drug Resist. 2006;12:145-8.

37. Meunier D, Jouy E, Lazizzera C, Kobisch M, Madec JY CTX-M-1 and CTX-M15 type b-lactamases in clinical Escherichia coli isolates recovered from food-producing animals in France. Int J Antimicrob Agents. 2006;28:402-7.

38. Blanc V, Mesa R, Saco M, Lavilla S, Prats G, Miro E, et al. ESBL- and plasmidic classCb-lactamase-producing E. coli strains isolated from poultry, pig and rabbit farms. Vet Microbiol. 2006;118:299-304. 
39. Wittum TE, Mollenkopf DF, Daniels JB, Parkinson AE, Mathews JL, Fry PR, et al. CTX-M-type expendedspectrum b-lactamases present in Escherichia coli from the feces of cattle in Ohio, United States. Foodborne Pathog Dis. 2010;7:1575-9.

40. Horton RA, Randall LP, Snary EL, Cockrem H, Lotz S, Wearing H, et al. Fecal carriage and shedding density of CTX-M extended-spectrum -lactamaseproducing Escherichia coli in cattle, chickens, and pigs: implications for environmental contamination and food production. Appl Environ Microbiol. 2011;77:3715-9. doi:10.1128/AEM.02831-10.. No. 11 0099-2240/11/\$12.00.

41. Ho PL, Chow KH, Lai EL, Lo WU, Yeung MK, Chan J, et al. Extensive dissemination of CTX-M-producing Escherichia coli with multidrug resistance to 'critically important' antibiotics among food animals in Hong Kong, 2008-10. J Antimicrob Chemother. 2011. doi:10.1093/jac/dkq539.

42. Liu JH, Wei SY, Ma JY, Zeng ZL, Lu DH, Yang GX, et al. Detection and characterization of CTX-M and CMY-2 b-lactamases among Escherichia coli isolates from farm animals in Guangdong Province of China. Int J Antimicrob Agents. 2007;29:576-81.

43. Marshall B, Tachibana C, Levy SB. Frequency of tetracycline resistance determinant classes among lactose-fermenting coliforms. Antimicrob Agents Chemother. 1983;24:835-40.

44. Sawant AA, Hegde NV, Straley BA, Donaldson SC, Love BC, Knabel SJ, et al. Antimicrobial-resistant enteric bacteria from dairy cattle. Appl Environ Microbiol. 2007;73(1):156-63.

45. Rao S, Van Donkersgoed J, Bohaychuk V, Besser T, Song XM, Wagner B, et al. Antimicrobial drug use and antimicrobial resistance in enteric bacteria among cattle from Alberta feedlots. Foodborne Patho Dis. 2010;7(4):449-57. doi:10.1089/fpd.2009.0400.

46. Hartnett E, Kelly L, Newell D, Wooldridge M, Gettinby G. A quantitative risk assessment for the occurrence of Campylobacter in chickens at the point of slaughter. Epidemiol Infect. 2001;127:195-206.

47. Boysen L, Knochel S, Rosenquist $H$. Survival of Campylobacter jejuni in different gas mixtures. FEMS Microbiol Lett. 2007;266(2007):152-7.

48. Brynestad S, Luber P, Braute L, Bartelt E. Quantitative microbiological risk assessment of campylobacteriosis cases in the German population due to consumption of chicken prepared in home. Int J Risk Assess Manag. 2008;8(2008):194-213.

49. Bull SA, Allen VM, Domingue G, Jørgensen F, Frost JA, Ure R, et al. Sources of Campylobacter spp. colonizing housed broiler flocks during rearing. Appl Environ Microbiol. 2006;72(1):645-65.

\section{Submit your next manuscript to BioMed Central and take full advantage of:}

- Convenient online submission

- Thorough peer review

- No space constraints or color figure charges

- Immediate publication on acceptance

- Inclusion in PubMed, CAS, Scopus and Google Scholar

- Research which is freely available for redistribution

Submit your manuscript at www.biomedcentral.com/submit 